\title{
EXPOSURE ASSESSMENT OF THE POPULATION IN POLAND TO THE TOXIC EFFECTS OF NICKEL FROM VEGETABLE AND THEIR PRODUCTS
}

\author{
Monika Mania ${ }^{I}$,Matgorzata Rebeniak ${ }^{I}$, Jacek Postupolski ${ }^{I}$ \\ ${ }^{1}$ National Institute of Public Health - National Institute of Hygiene, Department of Food Safety, \\ 00-791 Warsaw, Chocimska 24, Poland
}

\begin{abstract}
Background. According to the European Food Safety Authority (EFSA), vegetable and vegetable products can significantly contribute to dietary nickel intake. Consumption of vegetable across European Union can vary significantly and depends on consumption habits in individual Member States. Toxicity of Ni is dependent on the chemical form, the route of exposure and solubility of nickel compounds.

Objectives. Determination of nickel content in commercially available vegetables and vegetable products and assessment of consumer exposure to Ni intake with these groups of foodstuffs.

Materials and methods. 66 samples of vegetables and their products were analysed for nickel content. Nickel was determined after microwave mineralization of samples by atomic absorption spectrometry with a graphite furnace atomization (GFAAS). Nitric acid and perhydrol were used for the mineralization of the samples. The estimated exposure for adults and children was compared with the tolerable daily intake (TDI -Tolerable Daily Intake) set by the European Food Safety Authority at $2.8 \mu \mathrm{g} / \mathrm{kg}$ body weight (b.w.) per day.

Results. Mean (MB-middle bound) Ni content from all investigated vegetable samples was $0.09 \mathrm{mg} / \mathrm{kg}$ (95th percentile MB $0.23 \mathrm{mg} / \mathrm{kg}$ ). In vegetable products, mean Ni concentration was $0.191 \mathrm{mg} / \mathrm{kg}$ (95th percentile: $0.67 \mathrm{mg} / \mathrm{kg}$ ). The highest nickel level was determined in the sample of roman lettuce $(0.32 \mathrm{mg} / \mathrm{kg})$, whereas lowest contamination was observed in the sample of onion $(0.04 \mathrm{mg} / \mathrm{kg})$. Contamination of investigated fruiting and leaf vegetable with nickel was slightly higher than root and bulb vegetables. The estimated average adults exposure to nickel from vegetable taking into account maximum absorption was $4.8 \%$ of TDI and $16.8 \%$ of TDI and does not pose a health risk. Exposure to nickel from vegetable products was $1.9 \%$ and $6.8 \%$ TDI, respectively.

Conclusions. Obtained results demonstrate that dietary nickel intake from vegetables and their products do not constitute a significant health threat to consumers in Poland.
\end{abstract}

Key words: nickel, vegetable, vegetable products, exposure assessment, tolerable daily intake/nickel, TDI/nickel

\section{STRESZCZENIE}

Wprowadzenie. Warzywa i produkty warzywne należą do grupy środków spożywczych, które według Europejskiego Urzędu ds. Bezpieczeństwa Żywności (EFSA) mogą wnosić istotny udział do pobrania niklu z dietą. Spożycie warzyw w Unii Europejskiej może się znacznie różnić i zależy od nawyków konsumpcyjnych panujących w poszczególnych państwach członkowskich. Toksyczność niklu zależy od postaci chemicznej, drogi narażenia i rozpuszczalności związków niklu.

Cel badań. Oznaczenie zawartości niklu w warzywach i produktach warzywnych dostępnych w obrocie handlowym oraz ocena narażenia konsumentów na pobranie niklu z tymi grupami środków spożywczych.

Material i metody. Analizie na zawartość niklu poddano 66 próbek warzyw i ich produktów, pochodzących z obrotu handlowego. Zawartość niklu oznaczono po mineralizacji mikrofalowej próbek metodą absorpcyjnej spektrometrii atomowej z wykorzystaniem kuwety grafitowej (GFAAS). Do mineralizacji próbek wykorzystano kwas azotowy oraz perhydrol. Oszacowane narażenie w odniesieniu do osób dorosłych oraz dzieci porównano z wartością tolerowanego dziennego pobrania (TDI -Tolerable Daily Intake) ustaloną przez Europejski Urząd ds. Bezpieczeństwa Żywności ustaloną na poziomie 2,8 $\mu \mathrm{g} / \mathrm{kg}$ m.c./dzień).

Wyniki. Średnia zawartość Ni (MB - middle bound) ze wszystkich badanych próbek warzyw wyniosła 0,09 mg/kg (95-percentyl MB 0,23 mg/kg). W produktach roślinnych średnie stężenie Ni wynosiło 0,191 mg/kg (95-percentyl: 0,67 mg/kg). Najwyższy poziom niklu oznaczono w próbce sałaty rzymskiej $(0,32 \mathrm{mg} / \mathrm{kg})$, natomiast najniższe zanieczyszczenie niklem zaobserwowano w próbce cebuli $(0,04 \mathrm{mg} / \mathrm{kg})$. Zanieczyszczenie badanych warzyw owocowych i liściastych niklem było nieco wyższe niż warzyw korzeniowych i cebulowych. Oszacowane średnie narażenie dla osób dorosłych na nikiel pocho-

Corresponding author: Monika Mania, Department of Food Safety, National Institute of Public Health-National Institute of Hygiene, 00-791 Warsaw, 24 Chocimska street, Poland, phone +4822 5421 369, fax +48 225421 392, e-mail: mmania@pzh.gov.pl 
dzący z warzyw, biorąc pod uwagę maksymalne wchłanianie, wyniosło 4,8\% TDI i 16,8\% TDI i nie stanowi zagrożenia dla zdrowia. Narażenie na nikiel z produktów warzywnych wyniosło odpowiednio: 1,9\% i 6,8\% TDI.

Wnioski. Uzyskane wyniki wskazują, że pobranie niklu w diecie z warzyw i ich produktów nie stanowi istotnego zagrożenia dla zdrowia konsumentów w Polsce.

Słowa kluczowe: nikiel, warzywa, produkty warzywne, ocena narażenia, TDI/nikiel, tolerowane dzienne pobranie/nikiel

\section{INTRODUCTION}

Vegetables are important for human health because of their vitamins, minerals, phytochemical compounds, and dietary fiber content. Especially antioxidant vitamins (vitamin $\mathrm{A}, \mathrm{C}$ and $\mathrm{E}$ ), folic acid and dietary fiber content have important roles in human health. The naturally low fat and calorie content makes them especially recommended for a healthy diet. Adequate vegetable consumption can be protective some chronic diseases such as diabetes, cancer, obesity, metabolic syndrome, cardiovascular diseases, as well as improve risk factors. It has been estimated that every serving increase in vegetable consumption reduces the risk of cancer by $15 \%$, cardiovascular disease by $30 \%$ and mortality by $20 \%$, attributable to antioxidants such as ascorbic acid, vitamin E, carotenoids, lycopene, polyphenols [17, 20]. In addition to health aspects, consumption of vegetable may be associated with the intake of contaminants, i.e. heavy metals like lead, cadmium, mercury, nickel, arsenic as well as pesticides and nitrates. Risk and benefits analysis should be taking into account in case of vegetable before appropriate actions in area of risk management will be taken [19].

Such an analysis was carried out, among others, by European Food Safety Authority in case of nitrates in vegetable. Experts found that the health benefits of eating vegetables outweigh the risks associated with the presence of nitrates [20].

According to Central Office of Statistics mean monthly consumption of vegetable in Poland is 7.92 $\mathrm{kg}$ per capita including potatoes $2.97 \mathrm{~kg}$, whilst dried vegetables and other processed vegetables $1.49 \mathrm{~kg}$ [7]. Rapid economic growth and transition makes that consumption habits change significantly and contribution of vegetables in our diets started to increasing.

Accumulation of nickel in vegetables is associated with the levels of this metal in soil and in the air. The main source of nickel contamination is anthropogenic activity $[6,23]$. Increased nickel accumulation is observed in plants growing on acidic and wetland soils compared to other types of soil [10]. International Agency for Research on Cancer (IARC) has classified nickel compounds to Group I as substance carcinogenic to humans, while metallic nickel and nickel alloys to Group 2B as substance possibly carcinogenic to humans $[8,12,21]$.
The EFSA Panel on Contaminants in the Food Chain (CONTAM Panel) established a tolerable daily intake (TDI) of $2.8 \mu \mathrm{g} \mathrm{Ni} / \mathrm{kg}$ body weight (b.w.) per day. The benchmark dose lower limit $\mathrm{BMDL}_{10}$ of 1.1 $\mu \mathrm{g} \mathrm{Ni} / \mathrm{kg}$ b.w. associated with dermatitis following oral exposure to $\mathrm{Ni}$ based on dose-response analysis was also determined. For risk characterization the CONTAM Panel decided not to establish an acute reference dose, but to adopt a margin of exposure (MOE) approach $[12,21]$. Calculated value of MOE taking into account mean and 95th percentile acute exposure for all groups of population was below 10 which indicated to be of health concern. Dietary exposure to Ni is associated mainly with non-carcinogenic health effects on the gastrointestinal, hematological, neurological and immune system. Dietary exposure and exposure via drinking water provide most of the intake of $\mathrm{Ni}[12$, 13, 21, 27]. Ni absorption from the gastrointestinal tract in humans can vary significantly (between 1 and $40 \%$ ) depending on its chemical form, diet composition and fasting status [21].

According to EFSA vegetables and vegetable products are the main contributors to the dietary exposure to nickel similarly to grain and grain-based products, nonalcoholic beverages (except milk-based beverages), sugar and confectionery, legumes, nuts and oilseeds. In case of toddlers additional important contributors are milk and dairy products. Mean chronic dietary exposure to nickel, across EU countries, ranges from 2.0 ( elderly) to $13.1 \mu \mathrm{g} / \mathrm{kg}$ body weight (b.w.) per day (toddlers). The 95th percentile dietary exposure ranges from 3.6 (elderly) to $20.1 \mu \mathrm{g} / \mathrm{kg}$ b.w. per day (toddlers) [21].

Currently, binding EU legislation does not place any limits for nickel contamination in foodstuffs. The national regulation of the Ministry of Health sets out the requirements for nickel in drinking water, natural mineral, spring and table waters at the level of 0.020 $\mathrm{mg} / 1[15,16]$. Legislation on food additives gives purity criteria for nickel at $1-200 \mathrm{mg} / \mathrm{kg}$ [4].

Prior to accession to the EU in Poland, in accordance with national legislation, nickel content limits were set in a very limited groups of foodstuffs [14].

In order to determine the appropriate strategy for risk management, the European Commission has decided to develop recommendations for monitoring the level of nickel in food and feed in the years 2016-2018 $[2,3]$. The results of these studies will contribute to the further work of the Commission in this area. 
The study aims were to determine nickel content in vegetable and their products available on the market in Poland, along with estimating consumer exposure to nickel found in these products.

\section{MATERIALS AND METHODS}

The test samples consisted of 66 vegetable and their products. Among the vegetable samples were root, tuber, bulb, fruiting vegetables, brassica and leaf vegetables as well as their products, that are available on the Polish market.

Nickel was measured by in-house adapted method based on manufacturer of apparatus guideline and was fully validated and accredited according to standard PN-EN ISO/IEC 17025:2018.

\section{Apparatus and instrumentation}

An VARIAN SpectrAA 880Z atomic absorption spectrometer equipped with graphite furnace and Zeeman background correction was used. For graphite furnace measurements, argon was used as inert gas. Pyrolytic-coated graphite tubes (Agilent) without platform were used. The operating parameters for working conditions are presented in Table 1. Samples were injected into the graphite furnace using autosampler. The atomic absorption signal was measured as a peak surface mode against an analytical curve. Milestone MLS 1200 (Italy) microwave closed system at the stage of sample preparation was used.

\section{Reagents}

All reagents used were of an appropriately high purity. Nitric acid (65\%, Merck), hydrogen peroxide (for analysis 30\% Merck), hydrochloric acid (pur p.a not less than $30 \%$, Chempur), ascorbic acid (pure p.a. Poch), palladium matrix modifier for graphite furnace $-10.0 \pm 0.2 \mathrm{~g} / \mathrm{L}\left(\mathrm{Pd}\left(\mathrm{NO}_{3}\right)_{2} / \mathrm{HNO}_{3}\right.$ (Merck)), deionised water. The element standard solution used for calibration was produced by diluting a stock solution of $1 \mathrm{~g} / \mathrm{L}$ (GUM).

Recommended chemical matrix modifiers for measurement using flameless atomic absorption spectrometry should stabilize nickel compounds during the ashing stage among other a solution of palladium and a reducing agent such as ascorbic acid.

\section{Quality Assurance}

The accuracy of the method was verified by analysis of certified reference materials: BCR-679 (White cabbage ) and SRM-1515 (Apple leaves NIST).

\section{Sample preparation - microwave digestion}

Samples of approx. $0.5 \mathrm{~g}$ to $1 \mathrm{~g}$ were placed into mineralization vessels on the volume $100 \mathrm{~mL}$. Then
$5 \mathrm{~mL}$ of concentrated nitric acid and $1 \mathrm{~mL}$ hydrogen peroxide were added. After the reagents were added, the contents of the reaction vessel were mixed thoroughly to prevent clumping. After finished of the spontaneous reaction, the reaction vessels were quickly closed. The samples were then mineralized a pressure technique using microwave energy, in accordance with the guidelines of the microwave oven manufacturer. Digestion conditions for microwave system were as follows: $30 \mathrm{sec}$ for $250 \mathrm{~W}, 2 \mathrm{~min}$ for $0 \mathrm{~W}, 5 \mathrm{~min}$ for $250 \mathrm{~W}, 5 \mathrm{~min}$ for $400 \mathrm{~W}$ and $5 \mathrm{~min}$ for $600 \mathrm{~W}$, ventilation $5 \mathrm{~min}$.

The obtained solution, after quantitative transfer to a volumetric flask and filled with deionised water to a specific volume. Blanks as well as quality control samples were also prepared under analogous conditions.

\section{Calibration curve}

Scope of calibration curve: from $0 \mu \mathrm{g} / \mathrm{L}$ to $25 \mu \mathrm{g} / \mathrm{L}$.

Instrument parameters: Lamp Current 4mA, Slit $0.2 \mathrm{~nm}$, Wavelength $232.0 \mathrm{~nm}$

Table 1. Instrumental analytical conditions

\begin{tabular}{|c|c|c|c|}
\hline \multicolumn{5}{|c|}{ Furnace Operating Conditions } \\
\hline Step No. & $\begin{array}{c}\text { Temperature } \\
\left({ }^{\circ} \mathrm{C}\right)\end{array}$ & $\begin{array}{c}\text { Time } \\
(\mathrm{sec})\end{array}$ & $\begin{array}{c}\text { Gas flow } \\
(\mathrm{L} / \mathrm{min})\end{array}$ \\
\hline 1 & 85 & 5 & 3.0 \\
\hline 2 & 95 & 15 & 3.0 \\
\hline 3 & 120 & 10 & 3.0 \\
\hline 4 & 800 & 5 & 3.0 \\
\hline 5 & 800 & 1 & 3.0 \\
\hline 6 & 800 & 2 & 0 \\
\hline 7 & 2400 & 1.1 & 0 \\
\hline 8 & 2400 & 2 & 0 \\
\hline 9 & 2600 & 2 & 3.0 \\
\hline
\end{tabular}

\section{Statistical evaluation}

Statistical assessment of results was performed according the substitution method used by EFSA for the treatment of left-censored data - LC (below limits of quantification (LOQ was $0.031 \mathrm{mg} / \mathrm{kg}$ ). For results reported to be below the LOQ, the value equal to the LOQ (upper bound - UB), zero (lower bound - LB) or half the LOQ (medium or middle bound - MB) were used [22]. Left-censored data represented $33 \%$ of the analytical results.

\section{RESULTS AND DISCUSSION}

Concentration of the nickel in the analyzed samples is presented in Table 2 . 
Table 2. Nickel content in vegetable available in the Polish market, $\mathrm{mg} / \mathrm{kg}$

\begin{tabular}{|l|c|c|}
\hline \multirow{2}{*}{ Vegetable } & \multicolumn{2}{|c|}{ Nickel content } \\
\cline { 2 - 3 } & Mean & P95 \\
\hline \multirow{3}{*}{$\begin{array}{l}\text { Root, tuber and } \\
\text { bulb vegetable }\end{array}$} & LB: 0.08 & LB: 0.22 \\
\cline { 2 - 3 } & MB: 0.08 & MB: 0.17 \\
\cline { 2 - 3 } & UB: 0.09 & UB: 0.22 \\
\hline \multirow{2}{*}{$\begin{array}{l}\text { Leaf and fruiting } \\
\text { vegetables }\end{array}$} & LB: 0.10 & LB: 0.27 \\
\cline { 2 - 3 } & MB: 0.10 & MB: 0.27 \\
\hline \multirow{3}{*}{\begin{tabular}{l} 
All vegetables \\
\cline { 2 - 3 }
\end{tabular}} & UB: 0.11 & UB: 0.27 \\
\cline { 2 - 3 } & LB: 0.09 & LB: 0.23 \\
\cline { 2 - 3 } & UB: 0.09 & MB: 0.23 \\
\hline
\end{tabular}

LB - lower bound, MB - middle bound, UB - upper bound, P95 - 95th percentile

Mean (MB) nickel content from all investigated vegetable samples was $0.09 \mathrm{mg} / \mathrm{kg}$ (95th percentile MB $0.23 \mathrm{mg} / \mathrm{kg}$ ). In vegetable products, mean nickel concentration was $0.19 \mathrm{mg} / \mathrm{kg}$ (95th percentile was $0.67 \mathrm{mg} / \mathrm{kg}$ ). The highest nickel level was determined in the sample of roman lettuce $-0.32 \mathrm{mg} / \mathrm{kg}$, whereas lowest contamination of nickel was observed in the sample of onion at $0.04 \mathrm{mg} / \mathrm{kg}$. In case of vegetable products the highest result was obtained in a sample of dried beetroots $-0.74 \mathrm{mg} / \mathrm{kg}$.

Nickel contamination of vegetables was significantly lower as compared with results collected by EFSA from EU Member States and comparable with mean contamination reported in France for vegetables except potatoes and for starchy vegetables which was: $0.08 \mathrm{mg} / \mathrm{kg}$ and $0.07 \mathrm{mg} / \mathrm{kg}$ respectively [11, 21].

According to EFSA, the mean (LB-UB) contamination was in the range: $0.742-0.753 \mathrm{mg} / \mathrm{kg}$ (P95 $9.25 \div 9.25 \mathrm{mg} / \mathrm{kg}$ ). In case of starchy roots and tubers obtained results were significantly lower (LB-UB was $0.123 \div 0.150 \mathrm{mg} / \mathrm{kg} ;$ P95 $0.690 \div 0.690 \mathrm{mg} / \mathrm{kg}$ ) [21].

Contamination of investigated fruiting and leafy vegetable with nickel was: $0.10 \mathrm{mg} / \mathrm{kg}$ (mean MB) and 95th percentile $0.27 \mathrm{mg} / \mathrm{kg}$, and was slightly higher than roots and bulb vegetables: $0.08 \mathrm{mg} / \mathrm{kg}$ (MB) 95 th percentile $0.17 \mathrm{mg} / \mathrm{kg}$ respectively. The results reported in Pakistan indicate higher contamination of vegetables than in our studies, content of nickel in these studies was in the range $0.05 \mathrm{mg} / \mathrm{kg}-1.8 \mathrm{mg} / \mathrm{kg}$ [9]. Other than above French study indicate also higher contamination than in these studies. The mean (MB) value of nickel contamination in vegetable excluding potatoes was 0.21 $\mathrm{mg} / \mathrm{kg}$ ( 95 th percentile $0.63 \mathrm{mg} / \mathrm{kg}$ ), whilst for potatoes only mean value was $0.18 \mathrm{mg} / \mathrm{kg}$ (95th percentile 0.52 $\mathrm{mg} / \mathrm{kg}$ ) [1]. The survey conducted in Italy indicates comparable contamination of potatoes with results of these investigation, mean was in the range $0.076 \mathrm{mg} /$ $\mathrm{kg} \div 0.194 \mathrm{mg} / \mathrm{kg}$. Similar to our results were for vegetable, $0.039-0.159 \mathrm{mg} / \mathrm{kg}$ [5].
In a study conducted in UK, it was found that mean nickel concentration in green vegetables was $0.11 \mathrm{mg} /$ $\mathrm{kg}$ in other vegetables $0.09 \mathrm{mg} / \mathrm{kg}$ whilst in potatoes $0.10 \mathrm{mg} / \mathrm{kg}$ [24]. Similar results were obtained in the survey conducted by the Food Standards Agency (mean contamination of green vegetables was 0.086 $\mathrm{mg} / \mathrm{kg}$, potatoes $0.07 \mathrm{mg} / \mathrm{kg}$, and other vegetables $0.079 \mathrm{mg} / \mathrm{kg}$. Only contamination of canned vegetables was higher - mean $0.338 \mathrm{mg} / \mathrm{kg}$ [18].

Studies conducted in Iran indicated that the contamination of vegetables with $\mathrm{Ni}$ depends on seasons and the levels of nickel in vegetables. The higher contamination was observed in vegetables growing in spring than in vegetable growing in summer and autumn.

The mean concentrations of nickel in leafy vegetables obtained in this studies was $0.775 \pm 0.043 \mathrm{mg} /$ $\mathrm{kg}$ and was comparable with results reported in these studies [25].

Due to the limited amount of research conducted on the contents of nickel in specific vegetable products, often being regional products, it is difficult to compare the results obtained in this research for this groups of foodstuffs with the results obtained by other authors.

To assess the dietary exposure to nickel from commercially available vegetable and their products mean and high contamination levels (P95), middle bound (MB), were taken into account.

Taking into account the data of the Central Statistical Office, along with the data of WHO, GEMS/ Food Consumption Cluster Diets [26] on consumption of vegetables and their product, the intake of nickel from these foodstuffs was assessed and compared to the Tolerable Daily Intake (TDI) at $2.8 \mu \mathrm{g} / \mathrm{kg}$ body weight/ per day.

Mean (MB) intake of nickel by adult person from vegetables would be $12.1 \%$ TDI; at the P95 percentile contamination: $25.6 \%$ of TDI. Intake of nickel with vegetables by children taking into account mean $\mathrm{MB}$ contamination $42.2 \%$ of TDI (95th percentile $89.6 \%$ ).

Taking into account maximum absorption of nickel from the gastrointestinal tract in humans the mean intake would be $4.8 \%$ of TDI (at the P95 percentile contamination $10.2 \%$ of TDI) in adults and $16.8 \%$ of TDI (at the P95 percentile contamination 36\% of TDI) and in both cases does not pose a health risk.

Mean intake of nickel with vegetable products by adults and children taking into account maximum absorption will be: $1.9 \%$ and $6.8 \%$ of TDI respectively which also does not pose a health threat.

Estimated of daily intake based on obtained results from investigated foodstuffs is slightly higher than that reported in France [11].

Assuming a much higher variant of vegetable consumption in accordance with the WHO data, which for 
European countries is $478.7 \mathrm{~g} /$ person/day, the nickel intake by adults will be at average contamination and maximum nickel absorption from the gastrointestinal tract $8.8 \%$ and $22.5 \%$ of TDI value. For children, respectively: $30.8 \%$ and $78.7 \%$ of TDI value.

This exposure assessment is fraught with uncertainty related to the contribution of vegetables in a diet and real consumption and the absorption of nickel from the human digestive tract.

\section{CONCLUSIONS}

1. The content of nickel in the investigated samples of vegetable and their product is low and does not pose a health concern.

2. Levels of contamination found were mostly comparable to those reported in other countries

3. The obtained results will provide input to risk management in this area at UE level.

4. It is justified to continue a research on the content of nickel in other groups of foodstuffs that may make a significant contribution to intake of this element with a diet.

\section{Acknowledgement}

The study was performed under the scientific projects financed by the National Institute of Public HealthNational Institute of Hygiene, Warsaw, Poland (No 4/ ZŚ.1. 2017; No 4/ZŚ. 1. 2018; No BŻ-2.2019)

\section{Conflict of interest}

The authors declare no conflict of interest.

\section{REFERENCES}

1. Arnich N., Sirot V., Rivière G., Jean J., Nöel L., Guèrin T., Leblanc J-Ch.: Dietary exposure to trace elements and health risk assessment in the 2nd French Total Diet Study. Food Chem. Toxicol. 2012; 50: 24322449.

2. Commission Recommendation (EU) 2016/1111 of 6 July 2016 on the monitoring of nickel in food. OJ L $183,8.7 .2016$.

3. Commission Recommendation (EU) 2016/1110 of 28 June 2016 on the monitoring of the presence of nickl in feed. OJ L 183, 8.7.2016.

4. Commission Regulation (EU) No 231/2012 of 9 March 2012 laying down specifications for food additives listed in Annexes II and III to Regulation (EC) No $1333 / 2008$ of the European Parliament and of the Council. OJ L 83, 22.3.2012

5. Filippini T., Tancredi S., Malagoli C., Malavolti M., Bargellini A., Vescovi L., Nicolini F., Vinceti M.: Dietary Estimated Intake of Trace Elements: Risk Assessment in an Italian Population. Available online at :https://doi. org/10.1007/s12403-019-00324
6. González-Weller D, Gutiérrez ÁJ, Rubio C, Revert C, Hardisson A.: A total diet study of nickel intake in a Spanish population (Canary Islands). Int. J Food Sci. Nutr. 2012; 63(8):902-912.

7. GUS. Central Office of Statistics Database, Household budget survey in 2018. Warsaw 2019.

8. International Agency for Research on Cancer. Nickel and nickel compounds. IARC Monographs $100 \mathrm{C}$. Lyon; World Health Organization 2012.

9. Ismail F., Anjum MR., Mamon AN., Kazi TG.: Trace Metal Contents of Vegetables and Fruits of Hyderabad Retail Market. Pakistan Journal of Nutrition, 2011; 10: 365-372.

10. Kabata-Pendias A., Pendias H.: Pierwiastki śladowe w środowisku biologicznym. PWN, Warszawa 1979.

11. Leblanc J-Ch., Guerin T., Noël L., Calamassi-Tran G., Volatier J-L., Verger P. : Dietary exposure estimates of 18 elements from the 1st French Total Diet Study. Food Add. Contam. 2005; 22(7): 624-641.

12. Mania M., Szynal T., Wojciechowska-Mazurek M., Rebeniak M.: Nikiel w środkach spożywczych. Przem. Spoz. 2016; 70: 84-88 (in Polish).

13. Marzec Z., Marzec A. , Zaręba S.: Ocena pobrania niklu z dietami osób dorosłych. Żyw Człow 2007; 34:3-4: 885-888.

14. Ordinance of Polish Minister of Health of 30 April 2004 on the maximum levels of chemical and biological contaminants that may be found in food, food ingredients, allowed additional substances, processing aids or on the surface of food. Dz. U. No. 120. pos. 1257.

15. Ordinance of Polish Minister of Health of 31 March 2011 on the natural mineral waters, spring waters and potable waters. Dz. U. No. 85 , pos. 466.

16. Ordinance of Polish Minister of Health of 13 November 2015 on the quality of water intended for human consumption. Dz. U. 2015, pos. 1989.

17. Report of the Joint WHO/FAO Expert Consultation. Diet, nutrition and the prevention of chronic diseases. WHO Technical Report Series, No. 916 (TRS 916). Geneva 2003.

18. Rose M., Baxter M., Brereton N., Baskaran Ch.: Dietary exposure to metals and other elements in the 2006 UK Total Diet Study and some trends over the last 30 years. Food Add. Contam. 2010; 27(10): 1380-404.

19. Scientific opinion. Guidance on human health risk-benefit assessment of foods. EFSA Scientific Committee. EFSA Journal 2010; 8(7):1673

20. Scientific Opinion of the Panel on Contaminants in the food chain on nitrate in vegetables. EFSA Journal 2008; 689: 1-79.

21. Scientific opinion of the Panel on Contaminants in the Food Chain (CONTAM) on the risks to public health related to the presence of nickel in food and drinking water. EFSA Journal 2015; 13(2): 4002.

22. Scientific Report of EFSA. Management of left-censored data in dietary exposure assessment of chemical substances. EFSA Journal 2010; 8.

23. Shahzad B., Tanveer M., Rehman A., Cheema S.A., Fahad S., Rehman S., Sharma A.: Nickel; whether toxic or essential for plants and environment - a review. Plant Physiol. Biochem. 2018;132: 641-651. 
24. Sharma A.D.: Low Nickel Diet in Dermatology. Indian J. Dermatol. 2013; 58(3) :240

25. Shirkhanloo H., Alireza Hajiseyed Mirzahosseini S., Shirkhanloo N., Moussavi-Najarkola SA., Farahani H.: The evaluation and determination of heavy metals pollution in edible vegetables, water and soil in the south of Tehran province by GIS. Arch Environ Protect. 2015; 41: $64-74$
26. The GEMS/Food Consumption Cluster Diets, WHO, 2007.

27. Ysart G, Miller P, Crews H, Robb P, Baxter M, De L'Argy C, Lofthouse S, Sargent C, Harrison N.: Dietary exposure estimates of 30 elements from the UK Total Diet Study. Food in foods by flame atomic absorption spectrometry. Food Chem 2008; 108: 774-778.

Received: 17.11.2019

Accepted: 12.12.2019 